\title{
EFFECTS OF ORGANIC ENRICHMENT ON MACROFAUNA COMMUNITY STRUCTURE: AN EXPERIMENTAL APPROACH
}

\author{
Rodrigo Riera, ${ }^{1, * * *}$, Alicia Sacramento ${ }^{l}$, Óscar Perez ${ }^{l}$, Óscar Monterroso ${ }^{l}$, Eva Ramos ${ }^{l}$, \\ Myriam Rodríguez ${ }^{1}$ and Eduardo Almansa ${ }^{2}$ \\ ${ }^{1}$ Centro de Investigaciones Medioambientales del Atlántico (CIMA SL) \\ (Arzobispo Elías Yanes, 44, 38206 La Laguna, Tenerife, Canary Islands, Spain) \\ *Current address: Department of Biodiversity, \\ Qatar Environment and Energy Research Institute (QEERI), 5825 Doha, Qatar \\ ${ }^{2}$ Instituto Español de Oceanografía. Centro Oceanográfico de Canarias \\ (Avenida 3 de Mayo 73, Apdo. 1373, 38005, Santa Cruz de Tenerife, Canary Islands, Spain) \\ **Corresponding author: rodrigo@ cimacanarias.com
}

\begin{abstract}
A B S T R A C T
The determination of the resilience of benthic assemblages is a capital issue for the off-shore aquaculture industry in its attempts to minimize environmental disturbances. Experimental studies are an important tool for the establishment of thresholds for macrofaunal assemblages inhabiting sandy seabeds. An experiment was conducted with three treatments (Control, 1x and 3x), in which organic load (fish pellets) was added (1x (10 g of fish pellets) and $3 \mathrm{x}(30 \mathrm{~g}))$. A reduction in abundance of individuals and species richness was found as between the control and organic-enriched treatments. Significant changes in assemblage structure were also found, mainly due to the decrease of the sensitive tanaid Apseudes talpa in organically-enriched treatments. AMBI and M-AMBI indices were calculated and a decrease of ecological status was observed in treatment $3 \mathrm{x}$.
\end{abstract}

\section{RESUMO}

A determinação da resiliência das assembléias bênticas é um assunto fundamental para a indústria da aquicultura de mar aberto como tentativa de minimizar as perturbações ambientais. Estudos experimentais são ferramenta importante para o estabelecimento das linhas de base para as comunidades do fundo oceânico. Nesse sentido, um experimento foi conduzido sob três tratamentos (controle, 1x e 3x), nos quais o aporte orgânico (pelotas fecais de peixes) foi adicionado nas quantidades de $1 \mathrm{x}$ (10 g de pelotas fecais) e de 3 vezes $(30 \mathrm{~g})$. Os resultados mostram que foi encontrada redução na abundância de indivíduos e também no número de espécies entre o controle e os tratamentos com enriquecimento orgânico. Mudanças significativas na estrutura das assembleias também foram encontradas, principalmente devido ao decréscimo do tanaidáceo sensível Apseudes talpa nos tratamento enriquecidos. Os índices AMBI e M-AMBI foram calculados e um decréscimo do status ecológico foi observado no tratamento $3 \mathrm{x}$.

Descriptors: Finfish aquaculture, Organic enrichment, Mesocosm, Macrofauna, Apseudes talpa. Descritores: Aquacultura de mar aberto, Enriquecimento orgânico, Mesocosmo, Macrofauna, Apseudes talpa.

\section{INTRODUCTION}

One of the most common sources of contamination in coastal areas is the organic enrichment that can be generated by diverse human activities such as the operation of pipelines, runoffs and fish cages, among others (GRAY et al., 2002). Marine aquaculture has been steadily increasing worldwide in recent decades and is expected to continue to follow the same trend (FAO, 2007). The main negative impact of aquaculture activities is the resulting organic enrichment, due mainly to fish faeces and uneaten feed (FOCARDI et al., 2005).

The ultimate fate of suspended organic material is to sink and settle on seabeds, where it is incorporated into the sediment (LUND-HANSEN et al., 2004). The particulate organic material input from the water column to the seabed is low and benthic communities are supported by relatively minor rates of organic matter and nutrient flux (LAWSON et al., 2012). However, the organic enrichment of sediments tends to be accompanied by the development of reducing conditions on the seabed and the 
deoxidization of bottom water, as a result of the decomposition of abundant organic matter (TSUTSUMI, 1990).

There is a general pattern of distribution of benthic macrofauna along a gradient of organic enrichment of the sediment (PEARSON; ROSENBERG, 1978). Benthic communities in most organically enriched sediments with the most disturbed environments are simple ones, lacking in diversity, and are gradually replaced by more diverse communities after a decrease in the additional organic discharge to the bottom. Such changes in the physicochemical characteristics of the sediment might have a great impact on benthic assemblages (WU et al., 1994). Previous studies have demonstrated that perturbations induced by off-shore cages, by increasing the load of organic material beneath farms, trigger a strong reduction of the benthic biomass and species richness (SANZ-LAZARO; MARIN, 2011), differing considerably from those of assemblages of undisturbed control stations (EDGAR et al., 2005).

Tolerant or opportunistic species ("positive pollution indicators") tend to dominate organically enriched environments and less tolerant or sensitive species ("negative pollution indicators") tend to become increasingly rare or disappear (BELAN, 2003). Several species such as the polychaetes Capitella spp. and Pseudopolydora paucibranchiata, the amphipod Corophium spp. and the mollusc Abra $a l b a$, among others have been extensively recorded in polluted sediments (NORKKO et al., 2006; RIERA et al., 2011). In the last decade, several biotic indices have been developed to establish a classification of benthic ecosystem health based on the whole benthic assemblage structure (GRALL; GLEMAREC, 1997; BORJA et al., 2003). These indices analyze environmental quality by comparing the proportion of species typical of unpolluted conditions ("sensitive") (TATARANNI; LARDICCI, 2009). Two of the most commonly used indices in the Atlantic-mediterranean region are AMBI and M-AMBI (BORJA et al., 2000; MUXICA et al., 2007), used in the field monitoring assessment studies of off-shore fish cages (BORJA et al., 2009). The former indices have formerly been applied successfully in the Canary archipelago (RIERA et al., 2011). These indices offer a classification of pollution or disturbance of a site and represent benthic community health (MUXICA et al., 2007). Macrofaunal species are classified into 6 ecological groups, from I (undisturbed habitat) to VI (extremely disturbed) (BORJA et al., 2000).

Laboratory experiments with benthic fauna collected in the field have proved to be a suitable approach for the study of the effects of organic enrichment on marine communities (COULL; CHANDLER, 1992). Several field and laboratory experiments have dealt with the effect of different loadings of organic material added at the beginning of the experiment, community structure in undisturbed controls and treatments then being compared at the end of the experimental period (WEBB, 1996; SCHRATZBERGER; WARWICK, 1999). However, to our knowledge no experiments have so far been undertaken on the effects of fish pellets on macrofaunal assemblages. Hence, there is a lack of studies focusing on the effects of different concentrations and frequencies of organic dosages on benthic communities. The advantages of mesocosms to evaluate dose-response effects of macrofauna assemblages to organic enrichment are (i) the controlled physico-chemical conditions (temperature, $\mathrm{pH}$ and salinity, among others) and (ii) hydromorphological factors (currents, tides etc.) that contribute to dissipate the effects of organic enrichment on seabeds.

The main aims of the present study were:

I. to establish the effects of organic enrichment by fish pellets on macrofauna assemblage structure, and

II. to identify opportunistic species and those sensitive to organic load from fish pellets.

III. to check the reliability of AMBI and MAMBI indices in mesocosm studies.

\section{Material And Methods}

The sediment used in the present experiment was taken from an unpolluted subtidal area $(10 \mathrm{~m}$ deep) in Igueste de San Andrés bay (coordinates: $28^{\circ} 50^{\prime} 60^{\prime} \mathrm{N} / 16^{\circ} 16^{\prime} 89^{\prime} \mathrm{W}$ ). Sediment samples were gathered by scuba divers. Three replicates were analyzed before the experiment to determine the macrofauna assemblage structure present at the sampling location. Benthic samples were taken by hand with metallic cores $(20 \mathrm{~cm}$ inner diameter and 20 $\mathrm{cm}$ depth) by hammering these into the sediment, each replicate being separated by $1 \mathrm{~m}$ to avoid sediment disturbance and the bow-wave effect of pushing the cores. This sampling procedure has been systematically used in the Canary archipelago (RIERA et al., 2011, 2012a). Four replicates (each replicate corresponding to one benthic sample (core)) were maintained in plastic boxes in an open circuit inside 5001 tanks with photoperiod $12 \mathrm{~h}$ light/12 h darkness. The 12 boxes ( 4 replicates $\times 3$ treatments, explained below) were distributed randomly in 3 tanks, there being no block or barrier between the tanks.

\section{Experimental Design}

The experiment lasted 4 weeks and the whole macrofauna assemblage structure was used in each replicate of each treatment. All boxes were 
covered by a net to prevent any flight of organisms. Three treatments were conducted, "Control" (no added fish pellets) (4 replicates), " $1 \mathrm{x}$ Treatment" (10 g of fish pellets added each 2 weeks) (4 replicates) and " $3 \mathrm{x}$ Treatment" (30 $\mathrm{g}$ of fish pellets added each 2 weeks) (4 replicates). The fish pellets were spread out in each box of $1 \mathrm{x}$ and $3 \mathrm{x}$ treatments. These concentrations $(1 \mathrm{x}$ $(10 \mathrm{~g})$ and $3 \mathrm{x}(30 \mathrm{~g}))$ were established after a closecircuit recirculation experiment used as a pilot study. The food supply consisted of $4.5 \mathrm{~mm}$ wide fish pellets (EFYCO YM553) with a composition of $46 \%$ protein, $16 \%$ lipids and $23 \%$ carbohydrates.

At the beginning of the experiment, water quality parameters (temperature, salinity, dissolved oxygen and $\mathrm{pH}$ ) were measured to guarantee test validity in accordance with a standard protocol (APHA, 1995). These parameters were measured weekly throughout the experiment. Sediment samples were analyzed at the end of the experiment $\left(4^{\text {th }}\right.$ week) to determine macrofauna assemblage.

\section{Abiotic Variables}

Samples of organic matter were collected during the $2^{\text {nd }}, 3^{\text {rd }}$ and $4^{\text {th }}$ weeks of the experiment with each treatment $(1 \mathrm{x}$ and $3 \mathrm{x})$ and the control group. Walkley and Black's method (1934) was used to determ

ine the organic matter content in the sediment. The boxes were maintained in the natural photoperiod (from 10L:14D to 11L:13D hours of daylight and darkness), with a mean water temperature of $20.69 \pm 1.04^{\circ} \mathrm{C}$ and salinity of $36.8 \pm 0.14$ psu. The parameters were monitored twice a day, at $9.00 \mathrm{am}$ and $2.00 \mathrm{pm}$, and were measured by means of a portable multiparametric sonde.

\section{Macrofauna}

Samples were preserved in a $10 \%$ seawater formaldehyde solution, and subsequently decanted through a $0.5 \mathrm{~mm}$ mesh sieve. The fraction remaining was separated into different taxonomical groups under a binocular microscope, and preserved in $70 \%$ ethanol. Macrofaunal specimens were determined to species level, whenever possible, by means of a binocular microscope, or with a NIKON ECLIPSE microscope equipped with Nomarski interference.

\section{Statistical Analysis}

Biological descriptors of the community (abundance of individuals, species richness and Shannon's diversity) were calculated.

A non-parametric (Mann-Whitney) test was used for pairwise comparisons to establish differences between treatments in the content of the sedimentary organic matter. Differences in macrofauna abundance were tested by one-way ANOVA after verifying normality using the Kolmogorov-Smirnov test and the Levene test for homogeneity of variances. When there was no normality and/or homogeneity of variances, the Kruskal-Wallis ANOVA (KW ANOVA) test was used.

The affinities between macrofauna assemblages based on species composition were established using an n-MDS (non-metric multidimensional scale), abundance data being squareroot transformed and the Bray-Curtis similarity index used. ANOSIM analysis was conducted to compare macrofauna assemblage structure as between the treatments (Control, $1 \mathrm{x}$ and $3 \mathrm{x}$ ). Multivariate analyses were carried out using the PRIMER 6 package (Plymouth Routines In Multivariate Ecological Analysis) (CLARKE; WARWICK, 2001).

AMBI and M-AMBI indices

The classification of the identified species into the five ecological categories (groups I-V) was based upon the updated list of the AMBI program. AMBI and M-AMBI indices were calculated using AMBI 4.1 software (www.azti.es). Guidelines in deriving these indices (BORJA; MUXICA, 2005) were also applied. Species not considered in the list were classified according to the current literature, the authors' experience of their ecological distribution and the expertise of AZTI's staff.

\section{Results}

\section{Abiotic Variables}

The organic matter content varied from treatment to treatment, being lowest in the control group $(0.47 \pm 0.05 \%)$, intermediate for the $1 \mathrm{x}$ treatment $(0.53 \pm 0.06 \%)$ and highest for the $3 \mathrm{x}$ treatment $(1.06 \pm 0.05 \%)$ (Fig. 1). Significant differences were found between the $3 \mathrm{x}$ treatment and the others (Control-3x treatment, $\mathrm{U}=2.5, \mathrm{p}=0.05$ and Control-1x treatment, $U=2.39, p=0.05$ ).

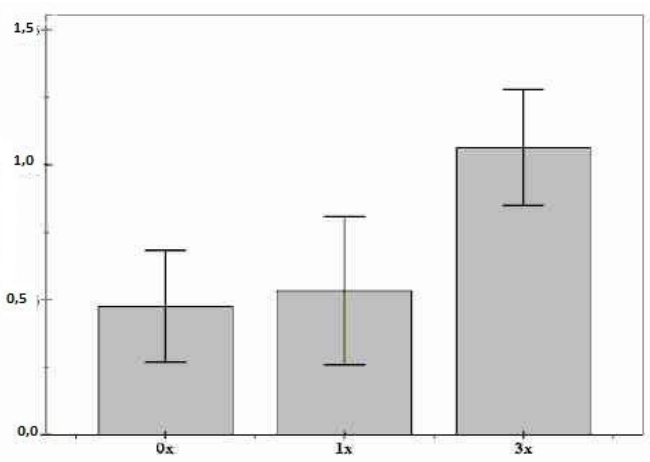

Fig. 1. Percentage of organic matter (mean \pm SE) in treatments $(0 \mathrm{x}, 1 \mathrm{x}$ and $3 \mathrm{x})$. 
Macrofauna Assemblage

Thirty species, belonging to 10 taxonomic groups (Amphipoda, Decapoda, Echinodermata, Mollusca, Nemertea, Oligochaeta, Ostracoda, Polychaeta and Tanaidacea), were present. The tanaid Apseudes talpa was the most abundant species (350 ind overall in the experiment) and the remaining taxa were represented by scarce abundances $(<50$ ind overall in the experiment) (Table 1).

Table 1. Macrofaunal abundances (mean $\pm \mathrm{SE}$ ) of carrying capacity treatments.

\begin{tabular}{|c|c|c|c|c|}
\hline Group & Species & $\mathbf{0 x}$ & $1 \mathbf{x}$ & $3 \mathbf{x}$ \\
\hline Amphipoda & $\begin{array}{l}\text { Ampelisca } \\
\text { brevicornis }\end{array}$ & $2.75 \pm 2.75$ & $1.25 \pm 2.5$ & $1 \pm 0$ \\
\hline Amphipoda & Bathyporeia sp. & $5.75 \pm 3.86$ & $0.5 \pm 0.58$ & 0 \\
\hline Amphipoda & $\begin{array}{l}\text { Harpinia } \\
\text { antennaria }\end{array}$ & $7.25 \pm 5.12$ & $2 \pm 1.63$ & $3 \pm 2.45$ \\
\hline Amphipoda & $\begin{array}{l}\text { Microdeutopus } \\
\text { anomalus }\end{array}$ & 0 & $1.25 \pm 1.89$ & 0 \\
\hline Amphipoda & $\begin{array}{l}\text { Urothoe } \\
\text { marina }\end{array}$ & $0.25 \pm 0.5$ & $1 \pm 1.41$ & 0 \\
\hline Decapoda & $\begin{array}{l}\text { Albunea } \\
\text { carabus }\end{array}$ & 0 & 0 & $0.25 \pm 0.5$ \\
\hline Echinodermata & $\begin{array}{l}\text { Brissus } \\
\text { unicolor }\end{array}$ & $0.5 \pm 1$ & 0 & 0 \\
\hline Mollusca & Bela ornata & 0 & 0 & $0.25 \pm 0.5$ \\
\hline Mollusca & $\begin{array}{l}\text { Jujubinus } \\
\text { exasperatus }\end{array}$ & 0 & $0.25 \pm 0.5$ & 0 \\
\hline Mollusca & $\begin{array}{l}\text { Lucinella } \\
\text { divaricata }\end{array}$ & $2.25 \pm 1.71$ & $0.5 \pm 0.58$ & 4 \\
\hline Mollusca & $\begin{array}{l}\text { Nassarius } \\
\text { cuvierii }\end{array}$ & $0.25 \pm 0.5$ & $0.5 \pm 1$ & 0 \\
\hline Mollusca & $\begin{array}{l}\text { Parvicardium } \\
\text { scriptum }\end{array}$ & $0.25 \pm 0.5$ & 0 & 0 \\
\hline Mollusca & Solemya togata & 0 & $0.25 \pm 0.5$ & 0 \\
\hline Mollusca & $\begin{array}{l}\text { Spisula } \\
\text { subtruncata }\end{array}$ & 0 & $0.25 \pm 0.5$ & $0.25 \pm 0.5$ \\
\hline Nemertea & Nemertea sp1 & 0 & $0.25 \pm 0.5$ & $0.25 \pm 0.5$ \\
\hline Nemertea & Nemertea sp2 & 0 & $0.25 \pm 0.5$ & 0 \\
\hline Oligochaeta & Grania $\mathrm{sp}$ & 0 & $0.5 \pm 0.58$ & $0.25 \pm 0.5$ \\
\hline Ostracoda & $\begin{array}{l}\text { Cypridina } \\
\text { mediterranea }\end{array}$ & $0.25 \pm 0.5$ & $1 \pm 0.82$ & 0 \\
\hline Ostracoda & $\begin{array}{l}\text { Cypridina } \\
\text { (Vargula) } \\
\text { norvegica }\end{array}$ & 0 & 0 & $0.75 \pm 0.5$ \\
\hline Polychaeta & $\begin{array}{l}\text { Aponuphis } \\
\text { bilineata }\end{array}$ & $0.5 \pm 1$ & 0 & $0.5 \pm 1$ \\
\hline Polychaeta & $\begin{array}{l}\text { Aricidea } \\
\text { assimilis }\end{array}$ & $0.25 \pm 0.5$ & $1.5 \pm 0.58$ & 0 \\
\hline Polychaeta & $\begin{array}{l}\text { Demonax } \\
\text { brachychona }\end{array}$ & 0 & 0 & $0.25 \pm 0.5$ \\
\hline Polychaeta & $\begin{array}{l}\text { Maldanidae } \\
\text { sp1 }\end{array}$ & $0.25 \pm 0.5$ & 0 & 0 \\
\hline Polychaeta & $\begin{array}{l}\text { Periquesta } \\
\text { canariensis }\end{array}$ & $1.75 \pm 1.71$ & $0.25 \pm 0.5$ & 0 \\
\hline Polychaeta & $\begin{array}{l}\text { Prionospio } \\
\text { steenstrupii }\end{array}$ & 0 & $0.5 \pm 0.58$ & $0.25 \pm 0.5$ \\
\hline Polychaeta & $\begin{array}{l}\text { Rhynchospio } \\
\text { glutaea }\end{array}$ & $0.25 \pm 0.5$ & 0 & 0 \\
\hline Polychaeta & $\begin{array}{l}\text { Scoloplos } \\
\text { (Leodamas) sp }\end{array}$ & $0.75 \pm 0.5$ & 0 & 0 \\
\hline Polychaeta & $\begin{array}{l}\text { Scoloplos } \\
\text { armiger }\end{array}$ & 0 & $0.25 \pm 0.5$ & $0.25 \pm 0.5$ \\
\hline Polychaeta & $\begin{array}{l}\text { Sigalion } \\
\text { squamatum }\end{array}$ & $0.25 \pm 0.5$ & 0 & $0.5 \pm 0.58$ \\
\hline Tanaidacea & Apseudes talpa & $42 \pm 28.34$ & $38.5 \pm 33.45$ & $7 \pm 4.55$ \\
\hline
\end{tabular}

The Control treatment showed the highest abundances $(65.5 \pm 32.09$ ind $)$ and the lowest were recorded in treatment $3 x(18.75 \pm 5.56$ ind $)$. Intermediate abundances were found in treatment $1 \mathrm{x}$ $(50.75 \pm 37.59$ ind) (Fig. 2). In all the treatments, the most abundant taxon was the tanaid Apseudes talpa, with abundances ranging from $7 \pm 4.55$ ind (Treatment $3 x$ ) to $42 \pm 28.43$ ind (Control) (Fig. 3). The second most abundant species was the amphipod Harpinia antennaria that ranged from $2 \pm 1.63$ ind (Treatment $1 \mathrm{x})$ to $7.25 \pm 5.12$ ind (Control).

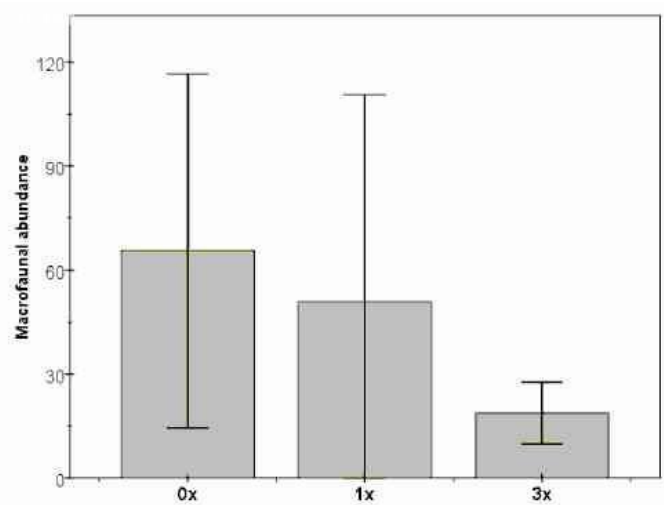

Fig. 2. Macrofaunal abundances (mean $\pm \mathrm{SE}$ ) in treatments $(0 \mathrm{x}, 1 \mathrm{x}$ and $3 \mathrm{x})$.

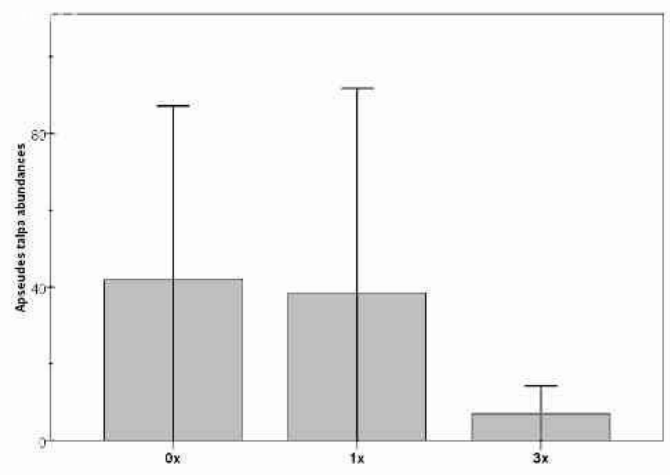

Fig. 3. Apseudes talpa abundances (mean $\pm \mathrm{SE}$ ) in treatments $(0 \mathrm{x}, 1 \mathrm{x}$ and $3 \mathrm{x})$.

Macrofauna assemblage structure showed significant differences between the treatments (oneway ANOSIM, $\mathrm{R}=0.546, \mathrm{p}=0.001)$. Post-hoc analysis showed significant differences between the $3 \mathrm{x}$ and $1 \mathrm{x}$ treatments $(\mathrm{R}=0.74, \mathrm{p}=0.029)$ and the $3 \mathrm{x}$ and Control $(\mathrm{R}=0.583, \mathrm{p}=0.029)$. In contrast, the differences between the Control and $1 \mathrm{x}$ treatments were not consistent $(\mathrm{R}=0.375, \mathrm{p}=0.057)$ (Fig. 4). 


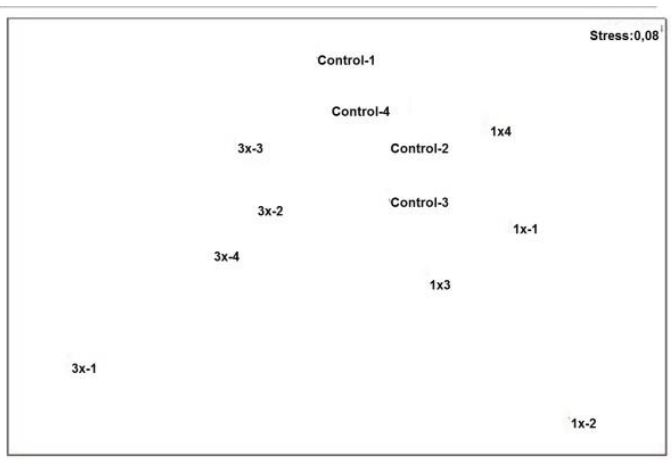

Fig. 4. n-MDS of treatments (Control, 1x and 3x).

\section{AMBI and M-AMBI}

The Control and $1 \mathrm{x}$ treatments obtained a high ecological status, according to the species richness (13-14 taxa). The $3 \mathrm{x}$ treatment was characterized by a lower ecological status ("good") due to the low species richness (8 taxa) (Table 2).

The AMBI and M-AMBI values of the three treatments (Control, $1 \mathrm{x}$ and $3 \mathrm{x}$ ) were typical of slightly disturbed ecosystems. All the treatments were dominated by the ecological group III, with the exception of the $3 \mathrm{x}$ treatment $(50.7 \%$ of species belonging to group I). The second ecological group in importance was group I and the remaining ones were scarce $(<5 \%)$. The high percentages of group III are to be explained by the dominance of the tanaid Apseudes talpa in the assemblage structure of the treatments (Table 3).

Table 2. AMBI and M-AMBI values of treatments (Control, $1 \mathrm{x}$ and $3 \mathrm{x})$.

\begin{tabular}{lccccc}
\hline \hline Treatment & AMBI & $\begin{array}{c}\text { Shannon's } \\
\text { Diversity }\left(\mathbf{H}^{\prime}\right)\end{array}$ & $\begin{array}{c}\mathbf{N}^{\mathbf{0}} \\
\text { species }\end{array}$ & $\begin{array}{c}\text { M- } \\
\text { AMBI }\end{array}$ & $\begin{array}{c}\text { Ecological } \\
\text { status }\end{array}$ \\
\hline Control & 1.829 & 1.74 & 17 & $\mathbf{0 . 9 1}$ & High \\
$\mathbf{1 x}$ & 2.193 & 1.47 & 19 & $\mathbf{0 . 8 7}$ & High \\
$\mathbf{3 x}$ & 2.337 & 2.15 & 14 & $\mathbf{0 . 8 2}$ & Good \\
\hline
\end{tabular}

Table 3. Percentage of ecological groups, AMBI and ecosystem state of treatments (Control, 1x and 3x).

\begin{tabular}{|c|c|c|c|}
\hline & Control & $1 \mathbf{x}$ & $3 \mathbf{x}$ \\
\hline Group I (\%) & 32.7 & 17.3 & 50.7 \\
\hline Group II (\%) & 1.2 & 3 & 6.7 \\
\hline Group III (\%) & 66.1 & 77.7 & 40 \\
\hline Group IV (\%) & 0 & 1 & 1.3 \\
\hline Group V (\%) & 0 & 1 & 1.3 \\
\hline $\begin{array}{l}\text { Not assigned } \\
\text { species (\%) }\end{array}$ & 3.1 & 0.5 & 0 \\
\hline AMBI & 1.829 & 2.193 & 2.337 \\
\hline Perturbation rate & $\begin{array}{c}\text { Slightly } \\
\text { perturbed }\end{array}$ & $\begin{array}{c}\text { Slightly } \\
\text { perturbed }\end{array}$ & $\begin{array}{c}\text { Slightly } \\
\text { perturbed }\end{array}$ \\
\hline
\end{tabular}

\section{DisCUSSION}

The addition of fish pellets triggered a decrease in macrofauna abundances, this being greatest in Control, intermediate in the $1 \mathrm{x}$ treatment and lowest in the $3 \mathrm{x}$ treatment. No differences in species richness were found as between the Control and $1 \mathrm{x}$ treatments, a decrease was, however, encountered in the $3 x$ treatment. The addition of fish pellets affected the macrofauna assemblage structure of the $3 \mathrm{x}$ treatment significantly but no consistent differences were found between the other treatments ( $1 \mathrm{x}$ and Control). These differences were mainly to be explained by the variations in Apseudes talpa abundances, highest in the control samples, and the low abundances of this species were responsible for the high Shannon's diversity in the 3x treatment.

The genus Apseudes has been observed to be dominant in internal sites in harbours, subject to high concentrations of heavy metals (GUERRA-GARCIA; GARCIA-GOMEZ, 2004). Apseudes latreillii, a species very close related to A. talpa, belongs to the group of species that may occur under normal conditions, but whose assemblages are stimulated by organic enrichment (GRALL; GLEMAREC, 1997). In the Canary Islands, Apseudes talpa is one of the dominant species in undisturbed subtidal sandy substrates, being more abundant in fine sediments (RIERA et al., 2011). In the present study, A. talpa abundances decreased abruptly in the $3 x$ treatment, presenting maximum abundances in the control group (> 40 ind).

AMBI and M-AMBI indices showed typical values of "slightly disturbed" ecosystems in all the treatments (Control, Treatments $1 \mathrm{x}$ and $3 \mathrm{x}$ ). This category is systematically applied to the subtidal Canarian macrobenthic assemblages because of the dominance of the tanaid Apseudes talpa, belonging to ecological group III. This species dominates most of the subtidal sandy seabeds of the Canary archipelago overwhelmingly (RIERA et al., 2012a, b).

Our results are in agreement with previous experimental studies on the effects of organic enrichment on meiofauna (organisms between 0.063 and $0.5 \mathrm{~mm}$ long) assemblages, with a consistent reduction of abundance and species richness with increasing level of organic enrichment (SCHRATZBERGER; WARWICK, 1999). Callier et al. (2009) observed the disappearance of sensitive species and the appearance of opportunistic species that accompanied a shift to an organically-enriched environment. In the present study, this pattern was clearly observed in amphipod abundances, those of, e.g., Ampelisca brevicornis, Bathyporeia sp. and Harpinia antennaria, which decreased with organically-enriched treatment. A total of 4 species 
(the decapod Albunea carabus, the mollusk Bela ornata, the ostracod Cypridina (Vargula) norvegica and the polychaete Demonax brachychona) were present exclusively in the $3 \mathrm{x}$ treatment. The bivalve Lucinella divaricata showed highest abundances in the $3 \mathrm{x}$ treatment, its populations being favoured by organic enrichment. This species has previously been found at inner sites in harbours, characterized by fine sediments and intermediate content of sedimentary organic matter, in the Canary archipelago (RIERA et al., 2012b).

There are limits to the possibility of extrapolating from experimental studies to natural situations because of specific local problems such as the limited recruitment and migration of fauna, reduced macrofauna abundance and limited biodeposit resuspension (CALLIER et al., 2009), however, even so, they constitute an important tool for improving understanding of disturbances which result in environmental impacts (WEBB, 1996).

The results of this experimental study have capital management implications for off-shore aquaculture activities and constitute an important step towards evaluating the environmental carrying capacity of coastal sites for off-shore cages. Experimental studies of carrying capacity are crucial to determine the real effects of organic enrichment on recipient benthic assemblages, as well as of the carrying capacity of benthic assemblages regarding organic load in areas with known physico-chemical and oceanographic conditions (current intensity and direction, salinity, temperature, etc...).

The present study constitutes a first attempt to establish the carrying capacity of sandy unvegetated substrates in the study region; future carrying capacity studies are, however, necessary to establish accurately the resilience thresholds of benthic assemblages. More experimental studies on the effects of different types of pellets, intensities and frequencies of organic enrichment on community structure should be conducted in order to obtain reliable and detailed information about organic enrichment effects on recipient assemblages.

\section{AcKNowledgements}

The authors wish to thank COC (IEO-Centro Oceanográfico de Canarias) for the use of their logistic facilities and their supervision of the experiment throughout the study period. This study was supported by CDTI (Centro de Desarrollo Tecnológico Industrial) of the Ministry of Economy and Competition (Project "Modelling tool to predict the environmental response of organic load from aquaculture farms (cod. IDI-20100116)"

\section{REFERENCES}

APHA. Standard methods for examination of water and wastewater. 19.ed. Washington: American Public Health Associaton, American Public Health Association, American Water Works Association, Water Pollution Control Federation, 1995. 22 p.

BELAN, T.A. Benthos abundance pattern and species composition in conditions of pollution in Amursky Bay (the Peter the Great Bay, the Sea of Japan). Mar. Pollut. Bull., v. 46, n. 9, p. 1111-1119, 2003.

BORJA, A.; FRANCO, J.; PEREZ, V. A marine biotic index to establish the ecological quality of soft-bottom benthos within European estuarine and coastal environments. Mar. Pollut. Bull., v. 12, n. 4, p. 1100-1114, 2000.

BORJA, A.; MUXICA, I.; FRANCO, J. The application of a Marine Biotic Index to different impact sources affecting soft-bottom benthic communities along European coasts. Mar. Pollut. Bull., v. 46, n. 7, p. 835-845, 2003.

BORJA, A.; RODRIGUEZ, J. G.; BLACK, K.; BODOY, A.; EMBLOW, C.; FERNANDES, T. F.; FORTE, J.; KARAKASSIS, I.; MUXICA, I.; NICKELL, T. D.; PAPAGEORGIOU, N.; PRANOVI, F.; SEVASTOU, K.; TOMASETTI, P.; ANGEL, D. Assessing the suitability of a range of benthic indices in the evaluation of environmental impact of fin and shellfish aquaculture located in sites across Europe. Aquaculture, v. 293, n. 3/4, p. 231-240, 2009.

BORJA, A.; MUXICA, I. Guidelines for the use of AMBI (AZTI's Marine Biotic Index) in the assessment of the benthic ecological quality. Mar. Pollut. Bull., v. 50, n. 7, p. 787-789, 2005.

CALLIER, M. D.; RICHARD, M.; MCKINDSEY, C. W.; ARCHAMBAULT, M.; DESROSIERS, G. Responses of benthic macrofauna and biogeochemical fluxes to various levels of mussel biodeposition: an in situ "benthocosm" experiment. Mar. Pollut. Bull., v. 58, n. 10, p. 1544-1553, 2009.

CLARKE, K. R.; WARWICK, R. M. Changes in marine communities: an approach to statistical analysis and interpretation. 2. ed. Wellington: Primer-E: Plymouth Marine Laboratory, 2001. 176 p.

COULL, B. C.; CHANDLER, G. T. Pollution and meiofauna: field, laboratory and mesocosm studies. Oceanogr. Mar. Biol.: Ann. Rev., v. 30, p. 191-271, 1992.

EDGAR, G.; MCLEOD, C. K.; MAWBEY, R. B.; SHIELDS, D. Broad-scale effects of marine salmonid aquaculture on macrobenthos and the sediment environment in southeastern Tasmania. J. Exp. Mar. Biol. Ecol., v. 327, n. 1, p. 70-90, 2005.

FAO. The state of world fisheries and aquaculture 2006. Rome: United Nations, Food and Agricultural Organization, 2007. 162 p. (The state of world fisheries and aquaculture).

FOCARDI, S.; CORSI, I.; FRANCHI, E. Safety issues and sustainable development of European aquaculture: new tools for environmentally sound aquaculture. Aquacult. Int., v. 13, n. 1/2, p. 3-17, 2005.

GRALL, J.; GLEMAREC, M. Using biotic indices to estimate macrobenthic community perturbations in the Bay of Brest. Estuarine, Coastal Shelf Sci., v. 44, suppl. 1, p. 43-53, 1997. 
GRAY, J. S.; WU, R. S. S.; OR, Y.-Y. Effects of hypoxia and organic enrichment on the coastal marine environment. Mar. Ecol.: Prog Ser., v. 238, p. 249-279, 2002.

GUERRA-GARCIA， J. M.; GARCIA-GOMEZ， J. C. Crustacean assemblages and sediment pollution in an exception case study: a harbour with two opposing entrances. Crustaceana, v. 77, n. 3, p. 353-370, 2004.

LAWSON, S. E.; MCGLATHERY, K. J.; WIBERG, P. L. Enhancement of sediment suspension and nutrient flux by benthic macrophytes at low biomass. Mar. Ecol.: Prog. Ser., v. 448, p. 259-270, 2012.

LUND-HANSEN, L. C.; PEJRUP, M.; FLODERUS, S. Pelagic and seabed fluxes of particulate matter and carbon, and $\mathrm{C}: \mathrm{N}$ ratios resolved by sediment traps during a spring bloom, southwest Kattegat. J. Sea Res., v. 52, n. 2, p. 87-98, 2004.

MUXICA, I.; IBAIBARRIAGA, L.; SÁIZ, J. L.; BORJA, A. Minimal sampling requirements for a precise assessment of soft-bottom macrobenthic communities, using AMBI. J. Exp. Mar. Biol. Ecol., v. 349, n. 2, p. 323-333, 2007.

NORKKO, J.; THRUSH, S. F.; WELLS, R. M. G. Indicators of short-term growth in bivalves: detecting environmental change across ecological scales. J. Exp. Mar. Biol. Ecol., v. 337, n. 1, p. 38-48, 2006.

PEARSON, T. H.; ROSENBERG, R. Macrobenthic succession in relation to organic enrichment and pollution of the marine environment. Oceanogr. Mar. Biol. Ann. Rev., v. 16, p. 229-311, 1978.

RIERA, R.; MONTERROSO, O.; RODRIGUEZ, M.; RAMOS, E. Biotic indexes reveal the impact of harbour enlargement on benthic fauna. Chem. Ecol., v. 27, n. 4, p. 311-326, 2011.

RIERA， R.; DELGADO， J. D.; RODRÍGUEZ, M.; MONTERROSO, O.; RAMOS, E. Macrofaunal communities of threatened subtidal mäerl seabeds on Tenerife (Canary Islands, north-east Atlantic Ocean) in summer. Acta Oceanol. Sin., v. 31, n. 1, p. 98-105, 2012a.
RIERA, R.; MONTERROSO, O.; NÚÑEZ, J. Effects of granulometric gradient on macrofaunal assemblages in Los Cristianos harbor (Tenerife, Canary Islands). Arquipélago: Life Mar. Sci., v. 29, p. 33-42, 2012 b.

SANZ-LAZARO, C.; MARIN, A. Diversity patterns of benthic macrofauna caused by marine fish farming. Diversity, v. 3, n. 2, p. 176-199, 2011. [Review].

SCHRATZBERGER, M.; WARWICK, R. M. Differential effects of various types of disturbances on the structure of nematode assemblages: an experimental approach. Mar. Ecol.: Prog. Ser., v. 181, p. 227-236, 1999.

TATARANNI, M.; LARDICCI, C. Performance of some biotic indices in the real variable world: a case study at different spatial scales in North-Western Mediterranean Sea. Environ. Pollut., v. 158, n. 1, p. 26-34, 2010.

TSUTSUMI, H. Population persistence of Capitella sp. (Polychaeta: Capitellidae) on a mud flat subject to environmental disturbance by organic enrichment. Mar. Ecol.: Prog. Ser., v. 63, p. 147-158, 1990.

WALKLEY, A.; BLACK, I. A. An examination of the Degtjareff method for determining soil organic matter, and a proposed modification of the chromic acid titration method. Soil Sci., v. 37, n. 1, p. 29-38, 1934.

WEBB, D. G. Response of macro- and meiobenthos from a carbon-poor sand to phytodetrital sedimentation. J. Exp. Mar. Biol. Ecol., v. 203, n. 2, p. 259-271, 1996.

WU, R. S. S.; LAM, K. S.; MACKAY, D. W.; LAU, T. C.; YAM, V. Impact of marine fish farming on water quality and bottom sediment: a case study in the sub-tropical environment. Mar. Environ. Res., v. 38, n. 2, p. 115145, 1994.

(Manuscript received 19 November 2012; revised 23 September 2013; accepted 06 November 2013) 